position differ from other more anti-Semitic science fiction works of the time? Why was Vogel so pro-Ireland? Was it out of sympathy for a nationalist cause, empathy for a people similarly stereotyped like the Jews, or both? Interestingly enough, while Vogel remains very pro-British, he also appears to demonstrate a strong sense of colonial proto-nationalism, evident in the empire's Dominions forcing [my italics] Britain to accept Irish self-government and with urban Londoners being depicted on 'the verge of effeminacy' vis a vis the inhabitants of the new world (137). Such a contrast between Britain and the colonies is again very reminiscent of turn-of-the-century booster publications where the inhabitants of New Zealand are often described as 'the best of the British'.

Despite the novel's sometimes slow pace and contrived dialogue there are a variety of factors which make Anno Domini 2000 deserving of further study. Indeed, this text would make a great addition to any undergraduate course in nineteenth century New Zealand literature, particularly with its themes of gender, race, and nationalism, not to mention technological developments, future wars, and even a lost civilisation in the Antarctic. Combined with the new publication's beautiful print quality and updated typeset, as well as the clever use of the attractive 1940 Centennial Exhibition Certificate as a cover (which draws attention to the forward march of women and the contrast between the past/ future and old world/new world), Robinson has done a great service to draw our attention to this most interesting work in an often neglected genre.

Dominic Alessio is a Lecturer in History at Richmond, The American International University in London.

\title{
Magnitude Eight Plus: New Zealand's Biggest Earthquake.
}

Rodney Grapes.

Wellington: Victoria University Press, 2000.

Living in New Zealand means living with earthquakes, and many New Zealanders are intensely interested in 'the big one'. Every time they feel the ground move they are eager for information on the earthquake's magnitude and location. A recent moderate magnitude (6.3), deep earthquake in the central North Island resulted in 105,000 hits on the Institute of Geological \& Nuclear Sciences website during the following day.

Kōtare 4, no. 1 (2001), pp. 73-85. 
At magnitude 8.1-8.2, the 1855 Wairarapa earthquake was a veritable 'big one'. In this book Rodney Grapes provides a very readable account of the effects of the event - on the landscape, the infrastructure of the young colony, and the social fabric. It is required reading for anyone interested in knowing what the 'big one' might be like.

Throughout the book, Dr Grapes lets the eyewitnesses do the talking, with extensive extracts from first hand accounts. One is struck by the credibility and insight shown by these contemporary observers. In their descriptions we find many of the effects that we now associate with large shallow earthquakes worldwide, such as the amplification of ground motion on soft sediments compared to motion at rock sites, and the cracking of ridges caused by the concentration of shaking at ridge crests. We also get an insight into how each generation's interpretation of observations is coloured by the fashionable theories of the day. Prior to 1855, it was thought that all earthquakes were associated with volcanic eruptions, and the large numbers of dead fish seen floating in Cook Strait after the earthquake were ascribed to a submarine volcanic eruption. But as is well described in the book, the 1855 earthquake provided the first dramatic proof that faulting over an 'amazing distance of 90 miles' was coupled with uplift of a huge area of land. The earthquake was directly related to this faulting, and not associated with volcanic activity.

By interspersing descriptions of the earthquake with other historical information, Dr Grapes successfully provides the social and political context of the earthquake sequence. Indeed, the book provides an excellent snapshot of life in central New Zealand 150 years ago. The earthquake sparked a major debate between rival Wellington newspapers at the time, as to whether their reporting of the shock was sensationalized or downplayed. This highlighted a sensitive and important issue at the time - the continued and uninterrupted immigration that was vital for the success of colonization. Meetings were organized in Wellington to downplay the worst effects of the earthquake and to emphasize the town's benefits. A similar debate followed the 1906 San Fransisco earthquake, and one can expect the same to recur when a future large earthquake hits a New Zealand city.

In truth, given the very large size of the 1855 earthquake, Wellington escaped with surprisingly few casualties. This was in large part due to a previous large earthquake in 1848, which had convinced many residents to build wooden dwellings, which withstood the shaking very well. On a longer timescale, the shock can be seen to have been economically beneficial. The coastal uplift produced in the event made travel to the Hutt Valley and the Wairarapa much easier. Also, analysis of building response during the 
earthquake led to further improvement in building standards. This is exemplified in the report of the commission charged with investigating building damage, included as an appendix to the book. I found myself reading this appendix with interest, discovering that the technique for measuring the strengths of different woods that one often sees at primary school science fairs is at least 150 years old.

So the book goes some way in rectifying the bad press of large earthquakes - they often produce longer term good as well as short term harm. They are also unforgettable, and produce some gripping yarns. It is the inclusion of many of these yarns which makes this account so readable. One of my favourites is the experience of the Bidwell family, who lived near what is now Martinborough. Immediately after the earthquake they camped on the lawn, as they feared their house would fall down. After two days they decided to move back into the house, even though the chimneys had fallen, all the doors were jammed, and the house itself had been shaken off its piles. No sooner had they sat down to their first meal when the table was overturned by a strong aftershock.

The book is well produced, and well illustrated with appropriate photographs and maps. It is also well edited, save for a few instances where the wrong units are given for measurements. Usually these mistakes are quite obvious to the reader, insofar as he or she will realize that kilometres of uplift during the earthquake shown in a diagram should read metres. At one point, the rate of convergence of the tectonic plates is given as ten times too high, due to a confusion of units. This would imply ten times as many earthquakes as we have now - not a nice thought.

Every earthquake teaches us something new, and very large earthquakes such as that in 1855 provide a treasure trove of information that can be revisited to test and even develop new hypotheses on their causes and effects. Such very large events are still relatively infrequent - events on the Wairarapa Fault similar to that in 1855 recur on average every 1650 years. So the work of $\mathrm{Dr}$ Grapes and his colleagues in collecting a comprehensive account of the earthquake provides a valuable resource for seismologists, engineers, planners, and not least the public at large. The Earthquake Commission is to be congratulated on supporting this excellent account of New Zealand's largest historical earthquake. It deserves to be popular, as it will inform readers of both the bad and good effects of the inevitable future 'big one'.

Dr Martin Reyners is a seismologist with the Institute of Geological \& Nuclear Sciences. His special interests are understanding how convergence between tectonic plates is accommodated by

Kōtare 4, no. 1 (2001), pp. 73-85. 
earthquakes, and quantifying how large future earthquakes between the plates might be.

\section{Tom's Letters: The Private World of Thomas King, Victorian Gentleman.}

Margot Fry.

Victoria University Press, Wellington, 2001.

Nineteenth-century men in New Zealand have typically been portrayed as dispassionate and detached from their emotional selves, preoccupied as they were with the physical demands of forging a new life. Marriage, too, has been shown in a similar light. As Margot Fry points out in the introductory chapter of Tom's Letters, 'publications about nineteenth-century relationships generally portray marriage as an institution characterised by domination and subjugation' (p. 13). Fry does not intend to tackle this assumption head on-or to turn it on its head-but she argues that this was not always the case. While not contesting the power structures that placed men as head of the household, she proposes that not all men saw marriage in this way. Nineteenth-century marriage was, she maintains, a far more complex institution that the rather rigid stereotype suggests.

Tom's Letters explores this theme by looking closely at the intersection of public and private worlds. Through Thomas King's private letters to his wife, Mary, we catch glimpses of his public life, his role in provincial and national politics. But we also read of his strong emotions towards his wife and children (whom he endearingly refers to as his 'little pledges'). Margot Fry, an independent Wellington historian, began the research for this book while National Library Fellow. Although the book is firmly based on the King family papers, and especially on King's letters to his wife, held by the Alexander Turnbull Library, it is also informed by a wider examination of their historical circumstances and recent scholarship.

The letters cover four quite discrete periods in Tom King's life: firstly a series of letters from his family in England from 1840 to 1848; second, those written in 1846 during his courtship of Mary Chilman, his future wife; thirdly, those from 1854 when Tom attended the General Assembly in Auckland; and lastly, those produced in 1860 when Mary and the children were sent to Nelson. The chapters are organised around these periods and have a fairly regular structure, comprising a historical preface, followed by the lightly edited letters themselves.

Kōtare 4, no. 1 (2001), pp. 73-85. 